\title{
PHOTOSYNTHETIC TRAITS OF CANOPY LEAVES OF Dinizia excelsa
} (Fabaceae)

\author{
Keila Rêgo Mendes ${ }^{2 *}$, Marcos Bento ${ }^{3}$ and Ricardo Antonio Marenco ${ }^{4}$ (C)
}

\begin{abstract}
${ }^{1}$ Received on 28.06.2018 accepted for publication on 30.08.2019.
${ }^{2}$ Instituto Nacional de Pesquisas da Amazônia, Programa de Pós-Graduação em Botânica, Manaus, AM - Brasil. E-mail: <keila.inpa@, gmail.com>.

${ }^{3}$ Instituto Nacional de Pesquisas da Amazônia, Programa de Pós-Graduação em Ciências de Florestas Tropicais, Manaus, AM - Brasil. E-mail: <bento.marcos@gmail.com>.

${ }^{4}$ Instituto Nacional de Pesquisas da Amazônia, Coordenação de Dinâmica Ambiental, Manaus, AM - Brasil. E-mail: <rmarenco@inpa.gov.br>. *Corresponding author.
\end{abstract}

\begin{abstract}
The response of leaf traits to irradiance and $\left[\mathrm{CO}_{2}\right]$ in canopy leaves of several tall trees remains to be determined under natural conditions. Thus, the objective of this work was to determine gas-exchange parameters in sun and shade leaves of Dinizia excelsa Ducke in 35-45 m tall trees of Central Amazonia. We assessed light saturated photosynthesis $\left(A_{\max }\right)$, stomatal conductance $\left(g_{s}\right)$, mesophyll conductance $\left(g_{m}\right)$, transpiration rates $(E)$, water use efficiency (WUE), intrinsic water use efficiency (WUEi), maximum electron transport rate $\left(J_{\max }\right)$, the maximum carboxylation rate of Rubisco $\left(V_{\text {cmax }}\right)$, intercellular $\mathrm{CO}_{2}$ concentration $\left(C_{\mathrm{i}}\right)$ specific leaf area (SLA) and fresh leaf thickness. We also estimated the $\mathrm{CO}_{2}$ concentration at the chloroplast level $\left(C_{\mathrm{c}}\right)$ and determined the light and $\mathrm{CO}_{2}$ saturated photosynthesis $\left(A_{\mathrm{pot}}\right) \cdot A_{\max }$ was obtained at light saturation $\left(1200 \mu \mathrm{mol} \mathrm{m}{ }^{-2} \mathrm{~s}^{-1}\right)$, whereas $A_{\text {pot }}, V_{\text {cmax }}, J_{\text {max }}$ and $\mathrm{g}_{\mathrm{m}}$ were obtained after constructing $A / C_{i}$ response curves. There was a significant difference between sun and shade leaves in $C_{\mathrm{i}}$ and $C_{\mathrm{c}}$, but for other parameters no differences were observed. $A_{\max }$ was positively correlated with $g_{\mathrm{s}}, g_{\mathrm{m}}$ and $E$, and there was also a significant correlation between $\mathrm{g}_{\mathrm{s}}$ and gm $(\mathrm{p} \leq 0.05)$, as well as between $J_{\max }$ and $V_{\text {cmax }}$. Thicker leaves had higher values of $A_{\max }, g_{\mathrm{s}}, C_{\mathrm{i}}, C_{\mathrm{c}}$ and $E$. $A_{\mathrm{pot}}$ was limited by the electron transport rate and by low $\mathrm{g}_{\mathrm{m}}$. The canopy of the tree caused a decrease in irradiance (30-40\%), but this reduction was not enough to reduce important photosynthetic parameters. Thus, all resources allocated to leaf production led to maximum use of the solar energy received by the leaves, which allowed this species to grow at fairly rapid rates.
\end{abstract}

Keywords: Mesophyll conductance; Maximum carboxylation rates of Rubisco; Central Amazonia.

\section{CARACTERÍSTICAS FOTOSSINTÉTICAS DE FOLHAS DE DOSSEL DE Dinizia excelsa (Fabaceae)}

RESUMO - A resposta das características foliares à irradiância e concentração de $\mathrm{CO}_{2}$ em folhas de dossel de várias espécies arbóreas de alto porte ainda permanece para ser determinada em condições naturais. Assim, o objetivo deste trabalho foi determinar parâmetros de troca gasosa em folhas de sol e sombra de Dinizia excelsa Ducke, em árvores de 35-45 $\mathrm{m}$ de altura, na Amazônia Central. Foram avaliados fotossintese saturada de luz $\left(A_{m a x}\right)$, condutância estomática $\left(g_{s}\right)$, condutância do mesofilo $\left(g_{m}\right)$, taxa de transpiração $(E)$, eficiência de uso de água (WUE), eficiência intrínseca de uso de água (WUEi), taxa máxima de transporte de elétrons $\left(J_{\max }\right)$, taxa máxima de carboxilação da Rubisco $\left(V_{c m a x}\right)$, concentração de $\mathrm{CO}_{2}$ intercelular $\left(C_{i}\right)$, área foliar específica (SLA) e a espessura da folha fresca. Também foi estimada a concentração de $\mathrm{CO}_{2}$ no nível de cloroplasto $\left(C_{c}\right)$ e determinada à fotossíntese saturada de luz e $\mathrm{CO}_{2}\left(A_{\text {poo }}\right)$. O $A_{\text {max }}$ foi obtido com saturação de luz (1200 umol $\left.\mathrm{m}^{-2} \mathrm{~s}^{-1}\right)$, enquanto que $A_{\text {pot }}, V_{c \max }, J_{\max }$ e $g_{m}$ foram obtidos após a construção de uma curva de resposta $A / C_{i}$. Houve diferença significativa entre as folhas de sol e sombra em $C_{i}$ e $C_{c}$, mas nenhuma diferença foi observada para outros parâmetros avaliados. $A_{\text {max }}$ foi positivamente correlacionado com $g_{s}, g_{m}$ e E, e também houve uma correlação significativa entre $g_{s}$ e $g_{m}(p \leq 0,05)$, bem como entre $J_{\max }$ e $V_{\text {cmax }}$. As folhas mais espessas apresentaram maiores valores de $A_{\max }, g_{s}, C_{i}, C_{c}$ e E. Apot foi limitado pela taxa de transporte de elétrons $e$ pelo baixo $g_{m}$. A folhagem da copa da árvore causou diminuição da luminosidade (30-40\%), mas essa redução 
mostrou-se insuficiente para reduzir parâmetros importantes da fotossíntese. Dessa forma, todo recurso alocado a produção de folhas levou a um máximo aproveitamento da energia solar recebida pelas folhas, possibilitando que esta espécie tenha um crescimento moderadamente rápido.

Palavras-Chave: Condutância do mesofilo; Taxa de carboxilação da Rubisco; Amazônia Central.

\section{INTRODUCTION}

In the last decades the effect of the increase of atmospheric $\mathrm{CO}_{2}$ concentration on plant physiology has been intensively investigated due to its presumed consequences on climate changes (Manter and Kerrigan, 2004; Knauer et al., 2019). It is well-known that stomata play an important role on carbon uptake, as they impose the first major diffusional limitation to $\mathrm{CO}_{2}$ diffusion, from the atmosphere to carboxylation sites (Nascimento and Marenco, 2013; Xiong et al., 2018). The photosynthetic capacity of a leaf depends on diffusive (i.e. stomatal conductance $-g_{\mathrm{s}}$ and mesophyll conductance $-g_{\mathrm{m}}$ ) and non-diffusive factors (i.e. the maximum carboxylation rate of Rubisco $-V_{\text {cmax }}$ and maximum electron transport rate, $\left.J_{\max }\right) \cdot V_{\text {cmax }}$ and $J_{\max }$ can be obtained from response curves of photosynthesis to intercellular $\mathrm{CO}_{2}$ concentration $-A / C_{\mathrm{i}}$ (Farquhar et al., 1980; Stinziano et al., 2019). Both $V_{\text {cmax }}$ and $J_{\max }$ are important parameters in modeling studies that aim to predict the impacts of climate change on plant functioning (Knauer et al., 2019).

Among the factors that affect photosynthesis, the response of stomatal functioning to environmental and endogenous factors has been the subject of much research (Terashima et al., 2011; Mendes and Marenco, 2014; Marenco et al., 2017). Although $\mathrm{g}_{\mathrm{m}}$ is also quite relevant to $\mathrm{CO}_{2}$ diffusion and photosynthesis, it attracted less attention in the past decades, but in recent studies, the importance of $g_{m}$ to carbon assimilation has been highlighted (Flexas et al., 2016; Knauer et al., 2019). Nevertheless, research is still needed to assess the relevance of $g_{\mathrm{m}}$ in tropical species, particularly the Amazonian species.

The strata of tropical forests, as well as gap opening and closing lead to the formation of a light gradient in the canopy of a tree. This gradient can lead to changes in the strategy of the leaf for light capture and light use efficiency, and thereby to variations in leaf structure and physiology (Givnish, 1984; Clark and Clark, 1992; Marenco et al., 2017). In fact, light is probably the most important environmental factor affecting plant establishment, growth and survival (Niinemets et al., 2015; Gitelson et al., 2017).

The angelim (Dinizia excelsa Ducke, Fabaceae) is an emerging tree that can reach $50-60 \mathrm{~m}$ in height and 1.0 to $1.8 \mathrm{~m}$ in diameter (Lorenzi, 1992). It has a dense wood $-0.91 \mathrm{~g} \mathrm{~cm}^{-3}$ (Fearnside, 1997), and trees over $20 \mathrm{~cm}$ in diameter have a growth rate of $5.30 \mathrm{~mm}$ per year (Schwartz et al., 2016). In the emergent phase, the angelim canopy stands out in the forest landscape; hence it is not shaded by neighboring trees. It has wide distribution in the Brazilian Amazon, can occur in density of one individual per 6 ha, and the trees have good silvicultural performance (Dick, 2001; Ferreira et al., 2004). Angelim is economically important in silvicultural systems and in the timber industry. The wood of angelim is resistant to the attack of fungi and termites, and it is used in the manufacture of decorative plates, construction, shipbuilding, woodworking, and carpentry (Melo and Varela, 2006; Oliveira et al., 2008). In addition, the angelim can also be used in garden and urban afforestation (Lorenzi, 1992).

Gas exchange studies of Amazonian tree species under natural conditions are relevant due to current trends in global warming and atmospheric $\mathrm{CO}_{2}$ enrichment (Magrin et al., 2014). Thus, measurements of gas exchange parameters (e.g. $g_{s}, A_{\max }, V_{\text {cmax }}$ and $\left.J_{\max }\right)$ in Amazonian species is of paramount importance for the construction of models aimed at predicting the performance of Amazonian ecosystems. Thus, the objective of this work was to determine the effect of leaf position in the canopy stratum on leaf traits of angelim trees in the Central Amazon. Leaf trait measurements included light saturated photosynthesis $\left(A_{\max }\right), g_{\mathrm{s}}, g_{\mathrm{m}}$, transpiration $(E)$, water use efficiency (WUE), intrinsic water use efficiency (WUEi), $J_{\max }, V_{\text {cmax }}$, intercellular $\mathrm{CO}_{2}$ concentration $\left(C_{\mathrm{i}}\right)$, specific leaf area (SLA) and fresh leaf thickness (FLT). It was also estimated the concentration of $\mathrm{CO}_{2}$ at chloroplast level $\left(C_{\mathrm{c}}\right)$ and determined light and $\mathrm{CO}_{2}$ saturated photosynthesis $\left(A_{\text {pot }}\right)$.

Revista Árvore 2019;43(4):e430409 


\section{MATERIALS AND METHODS}

The study was conducted at a 10-ha plot of a dense terra-firme forest fragment at the Colosso Reserve $\left(02^{\circ}\right.$ $\left.24^{\prime} 13.2^{\prime \prime} \mathrm{S}, 59^{\circ} 51^{\prime} 54^{\prime \prime} \mathrm{W}\right)$. The region has a humid equatorial climate, with annual precipitation of 2240 $\mathrm{mm}$, distributed over a rainy season from November to May (> $180 \mathrm{~mm}$ per month) and a mild dry season from June to September ( $\leq 100 \mathrm{~mm}$ per month). October is a transitional month. The average annual air temperature is $26.7^{\circ} \mathrm{C}$, and the average relative humidity is $84 \%$.

In this study, six trees (35-45 $\mathrm{m}$ in height and 1.30$2.00 \mathrm{~m}$ in diameter) of angelim (Dinizia excelsa Ducke, Fabaceae) were used. In the experiment we used a completely randomized design with two treatments and six replications (trees). The treatments were the leaves from two positions in the canopy: upper part of the tree (hereinafter referred to as sun leaves, which were under direct solar radiation) and lower part of the canopy (shade leaves), which received about $60-70 \%$ of total solar radiation. From these canopy strata branches were detached for data collection. They were about 7 to 12 $\mathrm{cm}$ in diameter and approximately $12 \mathrm{~m}$ in length. All branches were above the canopy of neighboring trees and the lower branches of a tree were shaded only by the upper ones. We used detached branches because of the impossibility of accessing the canopy of the tree for data collection.

To assess the effect of branch detachment on stomatal conductance $\left(g_{\mathrm{s}}\right)$, a previous study was carried out using two gas exchange systems (Li-6400, Li-Cor, Lincoln, USA), collecting data simultaneously from two small branches (about $4 \mathrm{~cm}$ in diameter) from the same tree, which was accessible from a 40-m observation tower. After a stabilization period of 15 minutes, one branch was randomly selected and kept intact while the other branch was severed from the tree by a rapid cut, without interrupting gas-exchange measurements. The measurement process on both leaves (i.e. from the undisturbed branch and the severed one) was uninterrupted for $60 \mathrm{~min}$, and during this time stomatal conductance remained similar in both branches. Thus, in the current experiment gas exchange and fluorescence data were measured within that time interval, and for further precaution data were collected on branches thicker than $4 \mathrm{~cm}$ in diameter.

Gas exchange and fluorescence measurements were made with a gas exchange system (Li-6400, Li-
Cor, Lincoln, NE) with a $2-\mathrm{cm}^{2}$ integrated fluorescence chamber head (Li-6400-40, Li-Cor). Just after detachment, the branch was taken to the gas exchange instrument for data collection. The time lag from branch detachment up to the leaflet insertion in the leaf chamber of the gas exchange system was about 10 minutes. After a stabilization period (5-10 $\mathrm{min})$ at ambient $\mathrm{CO}_{2}(380$

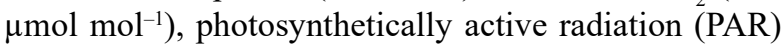
of $1200 \mu \mathrm{mol} \mathrm{m} \mathrm{m}^{-2} \mathrm{~s}^{-1}$ (light saturation) and ambient temperature $\left(27{ }^{\circ} \mathrm{C}\right)$, photosynthetic rates $(A)$ as a function of the intecellular $\mathrm{CO}_{2}$ concentration $-C_{\mathrm{i}}(A$ / $C_{\mathrm{i}}$ response curves) were measured. The $A / C_{\mathrm{i}}$ response curves were generated by increasing the reference $\mathrm{CO}_{2}$ concentration from 50 to $2000 \mu \mathrm{mol} \mathrm{mol}{ }^{-1}$ in nine steps, i.e. $380,250,100,50,380,550,1000,1,500$ and 2,000 $\mu \mathrm{mol} \mathrm{mol}{ }^{-1}$ (Long and Bernacchi, 2003). Light saturated photosynthesis $\left(A_{\max }\right)$ was determined at light saturation (a value determined in a previous experiment) and a $\mathrm{CO}_{2}$ concentration of $380 \mu \mathrm{mol} \mathrm{mol}{ }^{-1}$. Whereas the light and $\mathrm{CO}_{2}$ saturated photosynthesis (hereinafter termed potential photosynthesis $-A_{\text {pot }}$ ) was measured at light saturation and a reference $\mathrm{CO}_{2}$ concentration of 2000 $\mu \mathrm{mol} \mathrm{mol}{ }^{-1}$. The maximum carboxylation rate of Rubisco $\left(V_{\text {cmax }}\right)$ and maximum electron transport rate $\left(J_{\max }\right)$ were calculated according to Farquhar et al. (1980).

$A_{\mathrm{c}}=\left[V_{\text {cmax }}\left(C_{\mathrm{i}}-\Gamma^{*}\right)\right] /\left[C_{\mathrm{i}}+\mathrm{K}_{\mathrm{c}}\left(1+O / \mathrm{K}_{\mathrm{o}}\right)\right]$

$A_{\mathrm{j}}=\left[J_{\max }\left(C_{i}-\Gamma^{*}\right)\right] /\left(\left[4 C_{\mathrm{i}}+8 \Gamma^{*}\right)\right]$

Where $A_{\mathrm{c}}$ and $A_{\mathrm{j}}$ denote the net photosynthetic rates limited by Rubisco activity and electron transport rate $\left(A_{\mathrm{j}}\right)$, respectively. $\Gamma^{*}$ represents the $\mathrm{CO}_{2}$ compensation point in the absence of respiration in the light; $C_{\mathrm{i}}$ is the intercellular $\mathrm{CO}_{2}$ concentration, $O$ represents the oxygen concentration in the intercellular spaces; $K_{\text {c }}$ and $K_{\mathrm{o}}$ represent the Michaelis-Menten constant of Rubisco for carboxylation and oxygenation, respectively. $V_{\text {cmax }}$ values were standardized to $25^{\circ} \mathrm{C}$ (Medlyn et al., 1999).

The quantum yield of the photosystem II system $\left(\Phi_{\text {PSII }}\right)$ was calculated as previously described (Nascimento and Marenco, 2013). $C_{\mathrm{c}}$ values were determined according to Epron et al. (1995), whereas $\mathrm{g}_{\mathrm{m}}$ was obtained as follows: $g_{\mathrm{m}}=A /\left(C_{i}-C_{c}\right)$. We also calculated, water use efficiency (WUE) the photosynthesis to transpiration ratio $(A / E)$ and the intrinsic water use efficiency (WUEi) the $A / g_{\mathrm{s}}$ ratio. Data were collected 
from September to November 2010 from two healthy and physiologically mature leaflets per stratum, and from six trees and two canopy strata per tree.

To assess the effect of treatments on leaf morphology, fresh leaflet thickness (FLT) was measured in two leaflets from each canopy stratum on each tree with digital calipers $(0.01 \mathrm{~mm}$ accuracy). The leaflet thickness was determined in the middle portion of the leaves, avoiding major veins. The leaf area was determined with an area meter (Li-3000, Li-Cor), and the dry matter was determined after oven-drying at $72^{\circ} \mathrm{C}$ until constant mass. Specific leaf area (SLA) was determined as the leaf area to leaf mass ratio. For further information we also measured the chlo-

Table 1 - Light saturated photosynthesis $\left(A_{\max }\right)$, light and $\mathrm{CO}_{2}$ saturated photosynthesis $\left(A_{\mathrm{pot}}\right)$, stomatal conductance $\left(g_{\mathrm{s}}\right)$, mesophyll conductance $\left(g_{\mathrm{m}}\right)$, intercellular $\mathrm{CO}_{2}$ concentration $\left(C_{\mathrm{i}}\right)$, chloroplast $\mathrm{CO}_{2}$ concentration $\left(C_{\mathrm{c}}\right)$, vapor pressure deficit (VPD), leaf temperature $\left(T_{\text {leaf }}\right)$, water use efficiency (WUE), intrinsic water use efficiency $\left(\mathrm{WUE}_{\mathrm{i}}\right)$, the maximum carboxylation rate of Rubisco $\left(V_{\mathrm{cmax}}\right)$, electron transport rate $\left(J_{\max }\right), F_{\mathrm{v}} / F_{\mathrm{m}}$ ratio, specific leaf area (SLA), chlorophyll content, SPAD values, fresh leaf thickness (FLT), and absolute chlorophyll content $(a, b$ and $a+b)$ in sun and shade leaflets of Dinizia excelsa. Different capital letters denote significant differences ( $p=0.05$, t-test) between the canopy strata (sun and shade leaflet). Each value represents the mean $( \pm \mathrm{SE})$ of six trees and two leaflets per tree.

Tabela 1 - Fotossíntese saturada por luz $\left(A_{\max }\right)$, fotossíntese saturada por luz e $\mathrm{CO}_{2}\left(A_{\text {pot }}\right)$, condutância estomática $\left(g_{s}\right.$ ), condutância do mesofilo $\left(g_{m}\right)$, concentração intercelular de $\mathrm{CO}_{2}\left(C_{i}\right)$, concentração de $\mathrm{CO}_{2}$ de cloroplasto $\left(C_{c}\right)$, déficit de pressão de vapor (VPD), temperatura da folha $\left(T_{\text {leaf }}\right)$, eficiência no uso da água $(W U E)$, eficiência intrínseca no uso da água (WUE), taxa máxima de carboxilação de Rubisco $\left(V_{\text {cmax }}\right)$, taxa de transporte de elétrons $\left(J_{\max }\right)$,relação $F_{v} / F_{n}$, área foliar específica (SLA), conteúdo de clorofila, valores SPAD, espessura foliar fresca (FLT) e teor absoluto de clorofila ( $a, b$ e $a+b)$ em foliolos de sol e sombra de Dinizia excelsa. Letras maiúsculas diferentes indicam diferenças significativas ( $p=0,05$, teste $t$ ) entre os estratos do dossel (folhas do sol e folhas de sombra). Cada valor representa a média $( \pm S E)$ de seis árvores e dois folhetos (de duas folhas) por árvore.

\begin{tabular}{|c|c|c|}
\hline$\overline{\text { PARAMETER }}$ & SUN LEAFLET & $\begin{array}{c}\text { SHADE } \\
\text { LEAFLET }\end{array}$ \\
\hline 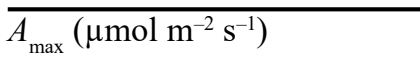 & $8.7 \pm 1.3 \mathrm{~A}$ & $5.9 \pm 0.7 \mathrm{~A}$ \\
\hline 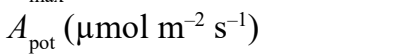 & $24.1 \pm 4.0 \mathrm{~A}$ & $19.3 \pm 2.1 \mathrm{~A}$ \\
\hline$g_{\mathrm{s}}\left(\mathrm{mol} \mathrm{m} \mathrm{m}^{-2} \mathrm{~s}^{-1}\right)$ & $0.13 \pm 0.03 \mathrm{~A}$ & $0.07 \pm 0.02 \mathrm{~A}$ \\
\hline$g_{\mathrm{m}}\left(\mathrm{mol} \mathrm{m}^{-2} \mathrm{~s}^{-1} \mathrm{bar}^{-1}\right)$ & $0.07 \pm 0.009 \mathrm{~A}$ & $0.05 \pm 0.005 \mathrm{~A}$ \\
\hline$C_{\mathrm{i}}\left(\mu \mathrm{mol} \mathrm{mol} \mathrm{m}^{-1}\right)$ & $232.6 \pm 11.4 \mathrm{~A}$ & $201.8 \pm 11.6 . \mathrm{B}$ \\
\hline$C_{\mathrm{c}}\left(\mu \mathrm{mol} \mathrm{\textrm {mol } ^ { - 1 } )}\right.$ & $107.9 \pm 5.3 \mathrm{~A}$ & $93.8 \pm 5.4 \mathrm{~B}$ \\
\hline$V_{\mathrm{cmax}}\left(\mu \mathrm{mol} \mathrm{m} \mathrm{m}^{-2} \mathrm{~s}^{-1}\right)$ & $41.1 \pm 4.9 \mathrm{~A}$ & $38.4 \pm 3.3 \mathrm{~A}$ \\
\hline 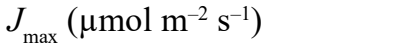 & $101.2 \pm 14.6 \mathrm{~A}$ & $80.6 \pm 8.3 \mathrm{~A}$ \\
\hline $\mathrm{VPD}(\mathrm{kPa})$ & $1.8 \pm 0.2 \mathrm{~A}$ & $1.9 \pm 0.2 \mathrm{~A}$ \\
\hline$T_{\text {leaf }}\left({ }^{\circ} \mathrm{C}\right)$ & $33.4 \pm 0.8 \mathrm{~A}$ & $33.6 \pm 0.8 \mathrm{~A}$ \\
\hline WUE $\left(\mathrm{mmol} \mathrm{mol}{ }^{-1}\right)$ & $4.4 \pm 0.6 \mathrm{~A}$ & $5.2 \pm 0.2 \mathrm{~A}$ \\
\hline $\mathrm{WUE}_{\mathrm{i}}\left(\mu \mathrm{mol} \mathrm{mol}{ }^{-1}\right)$ & $76.4 \pm 9.5 \mathrm{~A}$ & $108.3 \pm 13.3 \mathrm{~A}$ \\
\hline $\mathrm{F}_{\mathrm{v}} / \mathrm{F}_{\mathrm{m}}$ (unitless) & $0.78 \pm 0.005 \mathrm{~A}$ & $0.78 \pm 0.005 \mathrm{~A}$ \\
\hline $\operatorname{SLA}\left(\mathrm{m}^{2} \mathrm{~kg}^{-1}\right)$ & $7.8 \pm 0.5 \mathrm{~A}$ & $7.5 \pm 0.4 \mathrm{~A}$ \\
\hline FLT $(\mathrm{mm})$ & $0.20 \pm 0.003 \mathrm{~A}$ & $0.16 \pm \mathrm{B}$ \\
\hline SPAD & $68.1 \pm 4.4 \mathrm{~A}$ & $57.2 \pm 3.7 \mathrm{~A}$ \\
\hline Chlorophyll $a\left(\mu \mathrm{mol} \mathrm{m}{ }^{-2}\right)$ & $362.1 \pm 42.7 \mathrm{~A}$ & $317.6 \pm 19.4 \mathrm{~A}$ \\
\hline Chlorophyll $b\left(\mu \mathrm{mol} \mathrm{m}{ }^{-2}\right)$ & $93.6 \pm 26.0 \mathrm{~A}$ & $98.1 \pm 19.3 \mathrm{~A}$ \\
\hline Chlorophyll $\left.a+b(\mu \mathrm{mol} \mathrm{m})^{-2}\right)$ & $470.8 \pm 39.9 \mathrm{~A}$ & $415.7 \pm 27.9 \mathrm{~A}$ \\
\hline
\end{tabular}

\section{Revista Árvore 2019;43(4):e430409}


rophyll content of leaf pigment in $80 \%$ acetone and measured the SPAD values with a chlorophyll meter (SPAD-502-Minolta, Japan), as previously described (Mendes et al., 2013; Gouvêa and Marenco, 2018).

Data were subjected to analysis of variance (ANOVA) and the t test was used to determine significant differences between sun and shade leaflets. The relationships between quantitative variables (e.g. $A_{\max }$ versus $V_{\text {cmax }}, A_{\text {pot }}$ versus $J_{\max }$ ) were examined by regression analysis. Pearson's correlation coefficient was used to evaluate the relationships between gas exchange variables and morphological traits (SLA and leaflet thickness). Statistical analyzes were performed using Statistica 10.0 software (StatSoft, Tulsa, OK, USA).

\section{RESULTS}

There was no significant difference between sun and shade leaflets in $A_{\text {max }}, A_{\text {pot }}, g_{\mathrm{s}}, g_{\mathrm{m}}, V_{\max }, J_{\max }, \mathrm{VPD}$, $T_{\text {leaf }}$, WUE, WUEi SPAD values, and chlorophyll contents ( $\mathrm{p} \geq 0.05$; Table 1 ). Only $C_{\mathrm{i}}$ and $C_{\mathrm{c}}$ showed differences between canopy strata, i.e. sun versus shade leaflet ( $\leq 0.05$; Table 1$)$. On average, the $A_{\max }$ and $A_{\text {pot }}$ values were 8.7 and $24.1 \mu \mathrm{mol} \mathrm{m} \mathrm{m}^{-2} \mathrm{~s}^{-1}$ for the sun leaflets, whereas shade leaflets had $A_{\text {max }}$ and $A_{\text {pot }}$ values of 5.9 and $19.3 \mu \mathrm{mol} \mathrm{m} \mathrm{m}^{-2} \mathrm{~s}^{-1}$, respectively (Table 1). In ambient $\left[\mathrm{CO}_{2}\right]$, the $\mathrm{g}_{\mathrm{m}}$ values were $46 \%$ (sun leaflets) and $29 \%$ (shade leaflets) lower than those recorded for $g_{\mathrm{s}}$ (Table 1). The maximum quantum efficiency of PS II ( $\mathrm{F}_{\mathrm{v}} / \mathrm{F}_{\mathrm{m}}$ ratio) did not vary between sun and shade environment. There was a significant effect of the ambient condition on FLT ( $p \leq 0.05$; Table 1). Mean FLT values were 0.20 and $0.16 \mathrm{~mm}$ for the sunny and shade conditions, respectively. However, SLA showed no significant differences between the sun and shade environment ( $p \geq 0.05$; Table 1 ). As the ambient condition had no effect on gas exchange parameters ( $A_{\text {max }}, A_{\text {pot }}, g_{\mathrm{s}}$ and $g_{\mathrm{m}}$ ), data from both environments were pooled for correlation analysis.

$A_{\max }$ was positively correlated with $g_{\mathrm{s}}(\mathrm{r}=0.95$, Table 2$), g_{\mathrm{m}}(\mathrm{r}=0.96)$, and $E(\mathrm{r}=0.92)$. However, $A_{\text {max }}$ negatively correlated with VPD $(\mathrm{r}=-0.52), T_{\text {leaf }}$ $(\mathrm{r}=-0.32)$ and WUE $(\mathrm{r}=-0.28)$. There was a positive correlation between $g_{\mathrm{s}}$ and $\mathrm{g}_{\mathrm{m}}(\mathrm{r}=0.83$, Table 2$)$, and, it was also found that $g_{\mathrm{s}}$ decreased with increasing in VPD and $T_{\text {leaf }}(\mathrm{r}=-0.65$ and $\mathrm{r}=-0.46$; respectively). However, there was a weak correlation between $g_{\mathrm{m}}$ and VPD $(\mathrm{r}=-0.37)$ and $T_{\text {leaf }}(\mathrm{r}=-0.20)$, and between

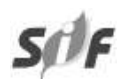

WUE and $g_{\mathrm{s}}(\mathrm{r}=-0.30)$ and $\mathrm{g}_{\mathrm{m}}(\mathrm{r}=-0.155)$. WUE and WUEi were positively correlated with the $g_{\mathrm{m}} / g_{\mathrm{s}}$ ratio $(\mathrm{r}=0.99$; Fig. 1).

At ambient $\mathrm{CO}_{2}$ concentration, $C_{\mathrm{i}}$ and $C_{\mathrm{c}}$ were positively correlated with $g_{\mathrm{s}}(\mathrm{r}=0.78)$ and $g_{\mathrm{m}}(\mathrm{r}=$ 0.42 , Table 2 ). There was also a positive correlation between $J_{\max }$ and $V_{\text {cmax }}(\mathrm{r}=0.81)$, and between $V_{\text {cmax }}$ (and $J_{\max }$ ) and $A_{\max }$ and $A_{\mathrm{pot}}$ (Table 2).

$V_{\text {cmax }}$ and $J_{\max }$ were positively correlated with $\mathrm{g}_{\mathrm{s}}(\mathrm{r} \cong 0.6)$ and $\mathrm{g}_{\mathrm{m}}(\mathrm{r} \cong 0.9$, Table 2$)$. Gas exchange parameters were correlated with SLA and FLT (Table 2). Thicker leaves had higher values of $A_{\max }(\mathrm{r}=$ $0.34), g_{\mathrm{s}}(\mathrm{r}=0.46), C_{\mathrm{i}}(\mathrm{r}=0.52), C_{\mathrm{c}}(\mathrm{r}=0.52)$ and $E(\mathrm{r}=0.38)$. SLA was negatively correlated with VPD, $T_{\text {leaf }}, V_{\text {cmax }}$ and $J_{\max }(\mathrm{p} \leq 0.05)$. On the other hand, FLT had no effect on $g_{\mathrm{m}}, V_{\mathrm{cmax}}$ and $J_{\max }(\mathrm{p} \geq$ 0.05). Finally, SLA increased with increasing LFT, which was not expected $(\mathrm{r}=0.58, \mathrm{p} \leq 0.001)$. In Figure 2 , irrespective of the environment (sun - shade), the initial portion of the curve showed a linear association between photosynthesis $(A)$ and $C_{\mathrm{i}}$ and $C_{\mathrm{c}}$ indicating a limitation imposed by Rubisco carboxylation rate. The increase of both $C_{\mathrm{i}}$ and $C_{\mathrm{c}}$ led $A$ to increase to the point of photosynthesis limitation by electron transport rate (dashed line in Figure 2). Below the colimitation point $\left(C_{i}\right.$ values of $433-544$

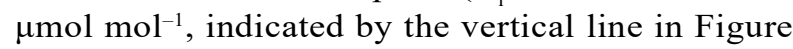
2 A, B), $A$ was limited by Rubisco carboxylation rates. The $C_{\mathrm{c}}$ values at the colimitation point were 201-252 $\mathrm{mol} \mathrm{mol}^{-1}$ (indicated by the vertical line in Figure $2 \mathrm{C}, \mathrm{D})$. On the other hand, above the colimitation point (high $\mathrm{CO}_{2}$ concentration) $A$ was limited by electron transport rates (dashed lines in Figure 2).

The $\mathrm{g}_{\mathrm{m}}$ values varied as a function of $C_{\mathrm{i}}$ or $C_{\mathrm{c}}$ (Fig. 3). At low $\mathrm{CO}_{2}$ concentrations $\left(\mathrm{C}_{\mathrm{i}} \leq 400 \mu \mathrm{mol}\right.$ $\left.\mathrm{mol}^{-1}\right), g_{\mathrm{m}}$ increased linearly with increasing $C_{\mathrm{i}}$ or $C_{\mathrm{c}}$ (Fig. 3). On the contrary, $g_{\mathrm{m}}$ decreased at high $\mathrm{CO}_{2}$ concentrations (Fig. 3). In comparison with $\mathrm{g}_{\mathrm{m}}$ values recorded at ambient $\left[\mathrm{CO}_{2}\right],\left(\mathrm{C}_{\mathrm{i}}\right.$ of $200-300 \mu \mathrm{mol} \mathrm{mol}{ }^{-}$ ), $\mathrm{g}_{\mathrm{m}}$ decreased $70 \%$ at high $\mathrm{CO}_{2}$ concentration (Fig. 3).

\section{DISCUSSION}

The mean $\mathrm{F}_{\mathrm{v}} / \mathrm{F}_{\mathrm{m}}$ value recorded in this study (0.78; Table 1) is within the range of values for non-stressed leaves, i.e. $\mathrm{F}_{\mathrm{v}} / \mathrm{F}_{\mathrm{m}}$ of about 0.80 (Björkman

Revista Árvore 2019;43(4):e430409 


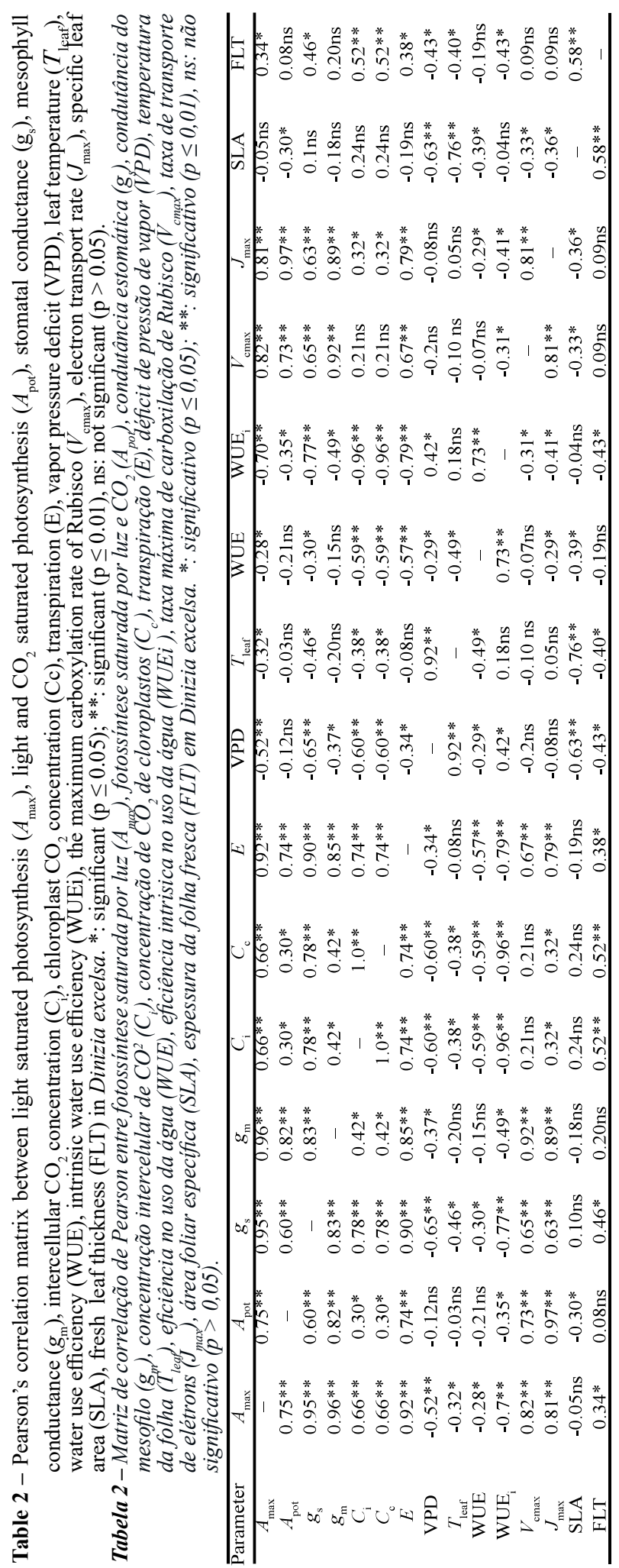

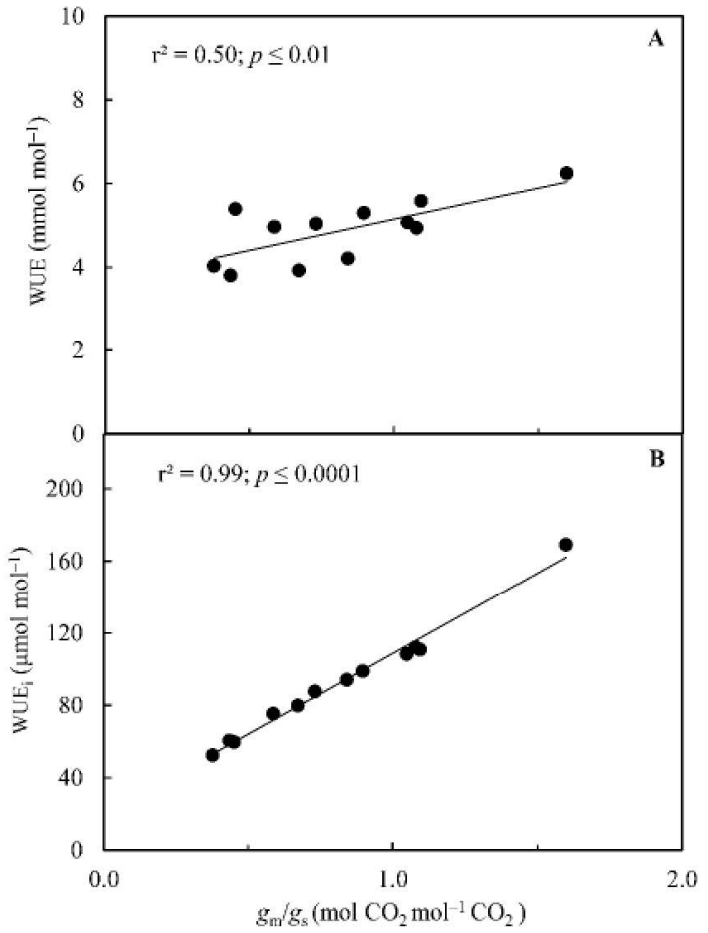

Figure 1 - Water use efficiency (WUE; A) and intrinsic water use efficiency (WUEi; B) as a function of the $\mathrm{gm} / \mathrm{gs}$ ratio in Dinizia excelsa. Each symbol corresponds to the mean of two leaflets per tree.

Figura 1 - Eficiência no uso da água (WUE; A) e eficiência intrínseca no uso da água (WUEi; B) em função da relação $g_{m} / g_{s}$ em Dinizia excelsa. Cada símbolo corresponde à média de dois foliolos (de duas folhas) por árvore.

and Demmig, 1987). Very low $\mathrm{F}_{\mathrm{v}} / \mathrm{F}_{\mathrm{m}}$ values, e.g. 0.60 or lower (Magalhães et al., 2009) often indicate the occurrence of photoinhibition. Therefore, it is concluded that in this study there was no photoinhibition of photosynthesis in D. excelsa.

The $A_{\max }$ values observed in this study are similar to those found in other studies, such as D. excelsa (Miranda et al., 2005), Minquartia guianensis, Coussapoa orthoneura and Protium opacum (Magalhães et al., 2009; Marenco et al., 2014). The chloroplast $\mathrm{CO}_{2}$ concentration $\left(C_{\mathrm{c}}\right)$ was around $50 \%$ lower than the concentration observed in the intercellular spaces (Table 1). Taking $C_{\mathrm{i}}$ as the base line, the decline in $C_{\mathrm{c}}$ is due to the barriers against $\mathrm{CO}_{2}$ diffusion, from the intercellular space to the carboxylation site in the chloroplast (Niinemets et al., 2015; Tosens and Laa-

\section{Revista Árvore 2019;43(4):e430409}




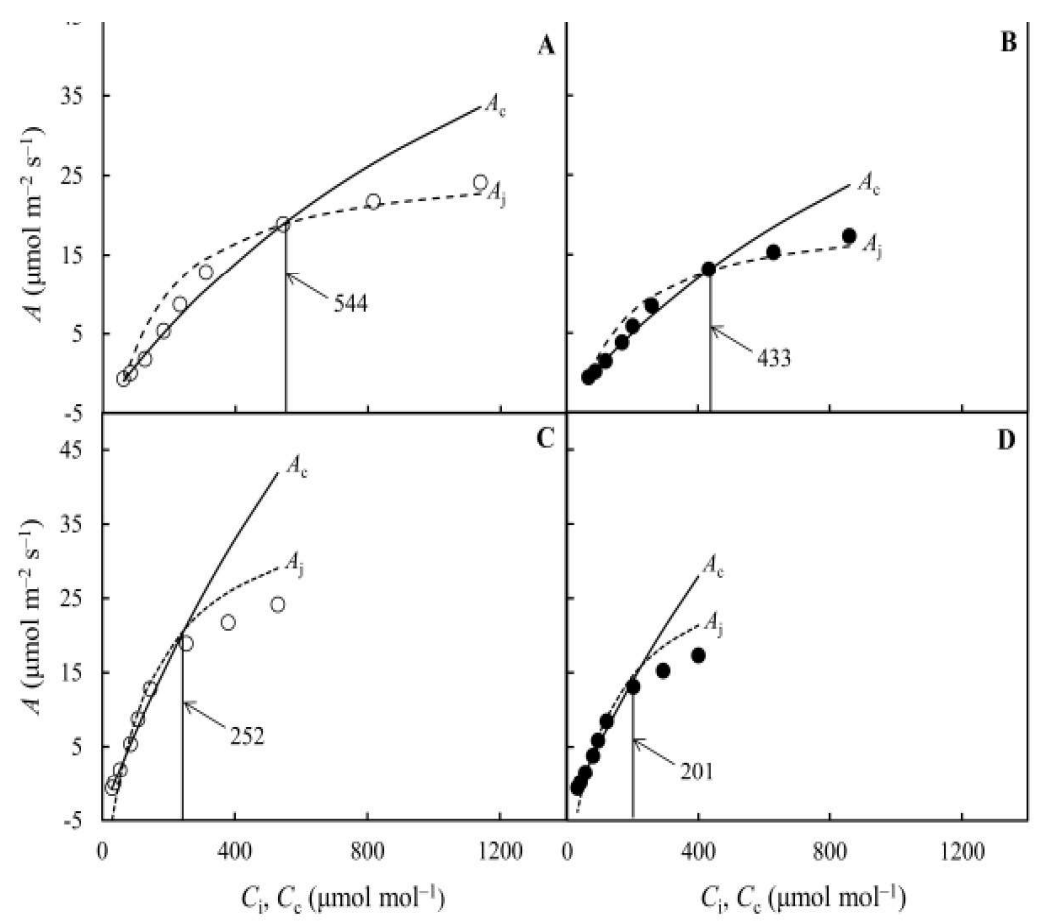

Figure 2 - Photosynthesis as a function of the intercellular $\left[\mathrm{CO}_{2}\right], C_{\mathrm{i}}(\mathrm{A}, \mathrm{B})$ and cloroplast $\left[\mathrm{CO}_{2}\right], C_{\mathrm{c}}(C, \mathrm{D})$ in sun leaflet (open circle, $\circ$ ) and shade leaflet (closed circle, $\bullet$ ). The solid line shows the photosynthesis limitation imposed by Rubisco carboxylation rate $\left(A_{c}\right)$, and the dashed line indicates the photosynthesis limitation imposed by electron transport rate $\left(A_{\mathrm{j}}\right)$. The vertical solid line shows the value of $C_{\mathrm{i}}$ and $C_{\mathrm{c}}$ at the colimitation point of $A_{\mathrm{c}}$ and $A_{\mathrm{j}}$. The numerals (in the panels) show the values for $C_{\mathrm{i}}$ and $C_{\mathrm{c}}$ in $\mu$ mol mol ${ }^{-1}$ at the colimitation point. Each symbol represents the mean of six trees and two leaflets per tree.

Figura 2 - Fotossíntese em função da concentração intercelular de [CO $\left.\mathrm{C}_{2}\right], \mathrm{C}_{i}(\mathrm{~A}, \mathrm{~B})$ e da $\left[\mathrm{CO}_{2}\right]$ no cloroplasto Cc (C, D) no folíolo de sol (círculo aberto, o) e foliolo de sombra (círculo fechado, •). A linha sólida mostra a limitação da fotossíntese imposta pela taxa de carboxilação de Rubisco (A), e a linha tracejada indica a limitação da fotossíntese imposta pela taxa de transporte de elétrons (A). A linha vertical sólida mostra o valor de $C_{i}$ e $C_{c}$ no ponto de colimitação de $A_{c}$ e $A_{j}$. Os numerais (nos painéis) mostram os valores para $C_{i} e$ $C_{c}$ em $\mu \mathrm{mol}$ mol $^{-1}$ no ponto de colimitação. Cada símbolo representa a média de seis árvores e dois folhetos (de duas folhas) por árvore.

nisto, 2018). The greatest resistance to internal diffusion of $\mathrm{CO}_{2}$ seems to be related to plasma membranes and chloroplast membranes (Warren, 2009; Peguero-Pina et al., 2017).

At the ambient $\mathrm{CO}_{2}$ concentration $(380 \mu \mathrm{mol}$ $\mathrm{mol}^{-1}$ ) there was a close relationship between $A_{\text {max }}$ and $g_{\mathrm{s}}$ and $g_{\mathrm{m}}$ (Table 2). This occurs because both conductances determine the $\mathrm{CO}_{2}$ flux to the carboxylation site in the chloroplast (Flexas et al., 2013). Stomatal and mesophyll resistance to $\mathrm{CO}_{2}$ flux account for about $40 \%$ of photosynthesis limitation in well-irrigated plants (Yamori et al., 2006; Tosens et al., 2016). Thus, the strong correlation between $g_{s}$ and $g_{m}$ indi-

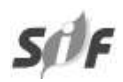

cates a coupling between these parameters. The high correlation between $A_{\max }$ and $g_{\mathrm{s}}\left(\right.$ and $g_{\mathrm{m}}$ ) suggests that diffusive factors were of paramount importance for determining carbon assimilation in $D$. excelsa. The decline of $g_{\mathrm{s}}$ under high VPD conditions corroborates that some ambient conditions can lead to a reduction in photosynthetic rates. Park and Furukawa (1999) showed that photosynthesis and stomatal conductance measured in tropical trees decreased due to increased VPD. Stomatal response to air humidity, temperature and VPD has been studied for decades, and it is known that stomata respond to changes in leaf tissue water content or to variations in guard cell water potential (Buckley, 2019).

\section{Revista Árvore 2019;43(4):e430409}




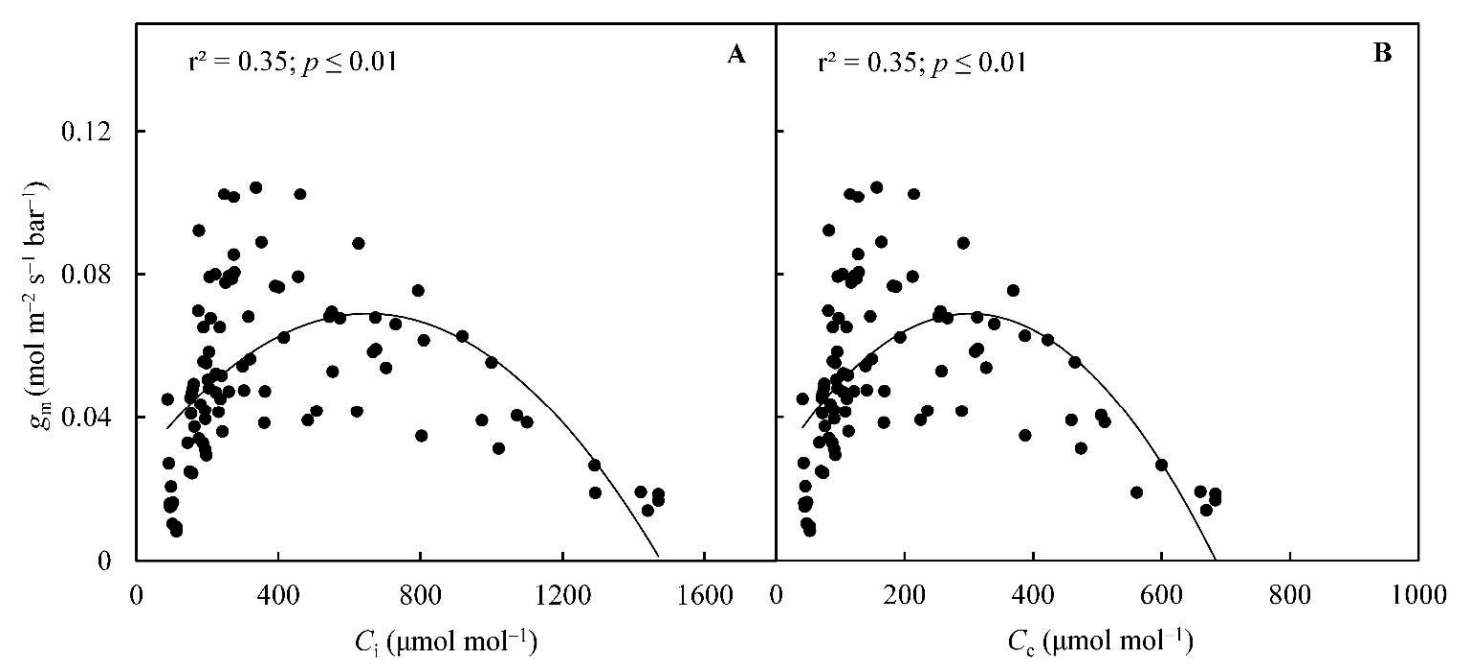

Figure 3 - Mesophyll conductance $\left(g_{\mathrm{m}}\right)$ in response to the intercellular $\mathrm{CO}_{2}$ concentration $\left(C_{\mathrm{i}}-A\right)$ and chloroplast $\left[\mathrm{CO}_{2}\right]\left(C_{\mathrm{c}}-B\right)$ in Dinizia excelsa. Each symbol corresponds to a value recorded on one leaflet.

Figura 3 - Condutância do mesofilo $\left(g_{m}\right)$ em resposta à concentração intercelular de $\mathrm{CO}_{2}\left(\mathrm{C}_{i}-A\right)$ e cloroplasto [CO $\mathrm{CO}_{2}$ $\left(C_{c}-B\right)$ em Dinizia excelsa. Cada símbolo corresponde a um valor obsservado em um foliolo.

Transpiration $(E)$ was strongly correlated with $g_{\mathrm{s}}$, which is expected as the stomata play a key role in the control of leaf transpiration. Although $g_{\mathrm{m}}$ is expected to have little impact on leaf transpiration (Ouyang et al., 2017), in this study we found a positive correlation between $g_{\mathrm{s}}$ and $g_{\mathrm{m}}$, which helps to explain the positive correlation between $g_{\mathrm{m}}$ and WUEi, as reported by Jahan et al. (2014). A high $g_{\mathrm{m}} / g_{\mathrm{s}}$ ratio contributes to increased water use efficiency, particularly under water stress. Thus, it has been suggested that plants with potential for acclimation to drought have a high $g_{\mathrm{m}}$ / $g_{\mathrm{s}}$ ratio (Giuliani et al., 2013). The strong relationship observed between the $g_{\mathrm{m}} / g_{\mathrm{s}}$ ratio and WUE and WUEi found in this study supports the hypothesis of coupling between $g_{\mathrm{s}}$ and $g_{\mathrm{m}}$. These results suggest that in Dinizia excelsa water efficiency can be increased by improving $\mathrm{g}_{\mathrm{m}}$.

Besides $g_{\mathrm{s}}, g_{\mathrm{m}}$ also affects the photosynthetic capacity of the leaf, as shown by the close correlation between $V_{\text {cmax }}, J_{\text {max }}$, and $g_{\mathrm{m}}$ (Table 2). Indeed, $V_{\text {cmax }}$ and $J_{\text {max }}$ were more influenced by $g_{\mathrm{m}}$ than by $\mathrm{g}_{\mathrm{s}}$. In Figure 2 , one can see that Rubisco carboxylation rate was the most limiting factor for photosynthesis (up to the $\mathrm{CO}_{2}$ concentration indicated by the arrows), which is in agreement with Sage and Kubien (2007) and Mendes et al. (2017). At higher $\mathrm{CO}_{2}$ concentrations, however, the electron transport rate became the most limiting factor a closer correlation between $A_{\text {pot }}$ and $J_{\max }$ was observed, which is in agreement with Mendes et al., (2017).

It was observed that $\mathrm{g}_{\mathrm{m}}$ showed a rapid response (minutes) to changes in $\mathrm{CO}_{2}$ concentration. However, it is unknown whether this response is a pattern also shared by other Amazonian tree species. At $C_{\mathrm{i}}$ values of $0-400 \mu \mathrm{mol} \mathrm{mol}{ }^{-1}\left(C_{\mathrm{c}}<200 \mu \mathrm{mol} \mathrm{mol}^{-1}\right), g_{\mathrm{m}}$ increased linearly with increasing $\mathrm{CO}_{2}$ until it reached

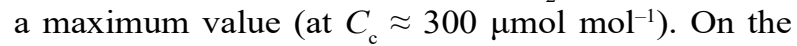
other hand, at high $C_{\mathrm{i}}$ values $\mathrm{g}_{\mathrm{m}}$ decreased with increasing $\mathrm{CO}_{2}$ concentration, which suggests that at that $\mathrm{CO}_{2}$ condition photosynthesis is no longer limited by the availability of $\mathrm{CO}_{2}$ at the intercellular spaces but by mesophyll resistance and electron transport rates.

Leaf thickness is one of the key leaf traits that affect $g_{\mathrm{m}}$ (Terashima et al., 2011). However, the significance of this effect was not detected in $D$. excel$s a$ probably because there was little variation in FLT $(0.16-0.21 \mathrm{~mm})$. However, it is worth noting that FLT positively affected $g_{\mathrm{s}}, C_{\mathrm{i}}$ and $C_{\mathrm{c}}$. This suggests that in thicker leaves there was an increase in the volume of intercellular space, perhaps as a mechanism to maximize mesophyll $\mathrm{CO}_{2}$ concentration. A large intercellular space can contribute to reduce the effect $\mathrm{CO}_{2}$ 
limitation under partial stomatal closure (Shao et al., 2008). SLA values recorded at the lower part of the canopy (shade leaflets, Table 2) were lower than those reported for understory trees (12 and $22 \mathrm{~m}^{2} \mathrm{~kg}^{-1}$ ) in the central Amazon (Mendes et al., 2013), which indicates that even leaves of the innermost part of the canopy were receiving relatively high levels of solar radiation. An increase in SLA is often related to a decrease in leaf thickness. Thus, the results presented in this study differ from the classical pattern that shows a negative relationship between SLA and leaf thickness (Niinemets, 1999). This discrepancy can be attributed to the fact that in this study leaf thickness was measured in fresh leaves, and variation in leaf water contents may lead to divergence with the most common SLA-leaf thickness relationship.

\section{CONCLUSIONS}

The canopy leaves of angelim causes a decrease in irradiance (30-40\%), which does not appear to be high enough to negatively affect important gas exchange parameters, such as $V_{\text {cmax }}$ and $J_{\max }$. This is quite important for the carbon economy of the tree, as it allows a maximum use of the solar energy received by the leaves. This ultimately contributes to enhance carbon uptake. As a result this species has a fairly fast growth rate, even when it produces wood of high density. On the other hand, an open canopy can lead to high transpiration rate, which might have a negative impact on photosynthesis if drought periods become longer as predicted by climate models.

In the study it is shown that the mesophyll resistance plays is an important role in $\mathrm{CO}_{2}$ diffusion. Therefore, it is recommended whenever possible to include $g_{m}$ values in gas exchange calculations to obtain more accurate values of photosynthetic parameters. At low $\left[\mathrm{CO}_{2}\right]$ the photosynthetic rates were limited by Rubisco carboxylation rate, but at high $\left[\mathrm{CO}_{2}\right]$ photosynthesis was limited by both $\mathrm{g}_{\mathrm{m}}$ and the electron transport rate. Changes in $\mathrm{CO}_{2}$ concentrations have an effect on $\mathrm{g}_{\mathrm{m}}$, which has its maximum at $C_{\mathrm{c}}$ values of about $300 \mu \mathrm{mol} \mathrm{mol}{ }^{-1}$. However, a substantial increase in atmospheric $\mathrm{CO}_{2}$ concentration may lead to an increase $(>50 \%)$ of the mesophyll resistance. The results presented in this study may be useful in the construction of climate models that aim to predict the effects of global climate change on the Amazon ecosystem.

\section{ACKNOWLEDGEMENTS}

To the Ministério da Ciência, Tecnologia, Inovações e Comunicações (MCTI-INPA). We thank the Coordenação de Aperfeiçoamento de Pessoal de Nível Superior (CAPES) for scholarships (KRM and $\mathrm{MB})$ and the Conselho Nacional de Desenvolvimento Cientifico e Tecnológico (CNPq) for fellowship to RAM.

\section{REFERÊNCIAS}

Björkman O, Demmig B. Photon yield of $\mathrm{O} 2$ evolution and chlorophyll fluorescence characteristics at $77 \mathrm{~K}$ among vascular plants of diverse origins. Planta. 1987;170(4):489-504.

Buckley TN. How do stomata respond to water status? New Phytologist. 2019;224(1). doi: 10.1111/ nph.15899.

Clark DA, Clark DB. Life history diversity of canopy and emergent trees in a neotropical rain forest. Ecol Monogr. 1992;62(3):315-344.

Dick CW. Habitat change, African honeybees and fecundity in the Amazonian tree Dinizia excelsa (Fabaceae). In: Bierregaard ROJ, Gascon C, Mesquita RCG, Lovejoy TE (Ed.). Lessons from Amazonia: the ecology and conservation of a fragmented tropical forest. New Haven: Yale University Press; 2001. p.146-157.

Epron D, Godard D, Cornic G, Genty B. Limitation of net $\mathrm{CO} 2$ assimilation rate by internal resistances to $\mathrm{CO} 2$ transfer in the leaves of two tree species (Fagus sylvatica L. and Castanea sativa Mill.). Plant Cell Environ. 1995;18(1):43-51.

Farquhar GD, von Caemmerer S, Berry JA. A biochemical model of photosynthetic $\mathrm{CO} 2$ assimilation in leaves of $\mathrm{C} 3$ species. Planta. 1980;149(1):78-90.

Fearnside PM. Wood density for estimating forest biomass in Brazilian Amazonia. For Ecol Manag. 1997;90(1):59-87.

Ferreira GC, Hopkins MJG, Secco RS. Contribuição ao conhecimento morfológico das espécies de leguminosae comercializadas no estado do Pará, como "angelim". Acta Amazonica. 2004;34(2):219232.

\section{Revista Árvore 2019;43(4):e430409}


Flexas J, Díaz-Espejo A, Conesa MA, Coopman RE, Douthe C, Gago J, et al. Mesophyll conductance to $\mathrm{CO} 2$ and Rubisco as targets for improving intrinsic water use efficiency in $\mathrm{C} 3$ plants. Plant Cell Environ. 2016;39(5):965-982.

Flexas J, Niinemets U, Gallé A, Barbour MM, Centritto M, Diaz-Espejo A, et al. Diffusional conductances to $\mathrm{CO} 2$ as a target for increasing photosynthesis and photosynthetic water-use efficiency. Photosynthesis Research. 2013;117(1-3):45-59.

Gitelson AA, Gamon JA, Solovchenko A. Multiple drivers of seasonal change in PRI: implications for photosynthesis 1. Leaf level. Remote Sensing of Environment. 2017;191:110-116.

Giuliani R, Koteyeva N, Voznesenskaya E, Evans MA, Cousins AB, Edwards GE . Coordination of leaf photosynthesis, transpiration, and structural traits in rice and wild relatives (Genus Oryza). Plant Physiology. 2013;162(3):1632-1651.

Givnish TJ. Leaf and canopy adaptations in tropical forests. In: Medina E, Mooney HA, Vázquez-Yánes C (eds). Physiological ecology of plants in the wet tropics. W. Junk, The Hague Netherlands; 1984. p.51-84.

Gouvêa PRS, Marenco RA. Is a reduction in stomatal conductance the main strategy of Garcinia brasiliensis (Clusiaceae) to deal with water stress?. Theoretical and Experimental Plant Physiology. 2018;30(4):321-33.

Jahan E, Amthor JS, Farquhar GD, Trethowan R, Barbour M. Variation in mesophyll conductance among Australian wheat genotypes. Functional Plant Biology. 2014;41(6):568-580.

Knauer J, Zaehle S, Kauwe MGde, Bahar NHA, Evans JR, Medlyn BE, et al. Effects of mesophyll conductance on vegetation responses to elevated $\mathrm{CO} 2$ concentrations in a land surface model. Global Change Biology. 2019;25(5):1820-1838.

Long SP, Bernacchi CJ. Gas exchange measurements, what can they tell us about the underlying limitations to photosynthesis? Procedures and sources of error. J Exp Bot. 2003;54(392):2393-2401.

Lorenzi H. Árvores Brasileiras: manual de identificação e cultivo da plantas nativas do Brasil. São Paulo: Plantarum, 1992. 352 p.
Magalhães NS, Marenco RA, Mendes KR. Aclimatação de mudas de acariquara à alta irradiância. Pesqui Agropecu Bras. 2009;44(7):687-694.

Magrin NGO, et al. Central and South America. In: Barros VR, Field CB (Ed.). In: Climate change 2014: Impacts, adaptation, and vulnerability. Part B: Regional aspects. Contribution of working group II to the fifth assessment report of the Intergovernmental Panel on Climate Change. New York, USA: Cambridge University Press, Cambridge, United Kingdom and; 2014. p.1499-1566.

Manter DK, Kerrigan J. A/Ci curve analysis across a range of woody plant species: influence of regression analysis parameters and mesophyll conductance. J Exp Bot. 2004;55 (408):2581-2588.

Marenco R, Camargo MAB, Antezana-Vera SA, Oliveira MF. Leaf trait plasticity in six forest tree species of central Amazonia. Photosynthetica. 2017;55(4):679-688.

Marenco RA. Antezana-Vera SA, Gouvêa PRS, Camargo M, Oliveira MF, Santos JKS. Fisiologia de espécies florestais da Amazônia: fotossíntese, respiração e relações hídricas. Revista Ceres. 2014;61(Suppl.):786-799.

Medlyn BE, Badeck FW, De Pury DGG, Barton CVM, Broadmeadow M, Ceulemans R, et al. Effects of elevated [CO2] on photosynthesis in European forest species: a meta-a of model parameters. Plant Cell Environ. 1999;22(12):1475-1495.

Melo MFF, Varela VP. Aspectos morfológicos de frutos, sementes, germinação e plântulas de duas espécies florestais da Amazônia: I. Dinizia excelsa Ducke (Angelim-Pedra). II Cedrelinga catenaeformis Ducke (Cedrorana) - Leguminosae: mimosoideae. Revista Brasileira de Sementes. 2006;28(1):54-62.

Mendes KR, Marenco RA. Is stomatal conductance of Central Amazonian saplings influenced by circadian rhythms under natural conditions?. Theor Exp Plant Physiol. 2014;26(2):115-125.

Mendes KR, Marenco RA, Magalhães NS . Crescimento e eficiência fotossintética de uso do nitrogênio e fósforo em espécies florestais da Amazônia na fase juvenil. Revista Árvore. 2013;37(4):707-716. 
Mendes KR, Marenco RA, Nascimento HCS. Velocidade de carboxilação da rubisco e transporte de elétrons em espécies arbóreas em resposta a fatores do ambiente na Amazônia Central. Ciência Florestal. 2017;27(3):947-959.

Miranda EJ, Vourlitis GL, Priante Filho N, Priante PC, Campelo JH, Suli GS, et al. Seasonal variation in the leaf gas exchange of tropical forest trees in the rain forest-savanna transition of the southern Amazon Basin. Journal of Tropical Ecology. 2005;21(4):451-460.

Nascimento HCS, Marenco RA. Mesophyll conductance variations in response to diurnal environmental factors in Myrcia paivae and Minquartia guianensis in Central Amazonia. Photosynthetica. 2013;51(3):457-464.

Niinemets Ü. Components of leaf dry mass per area - thickness and density - alter leaf photosynthetic capacity in reverse directions in woody plants. New Phytol. 1999;144(1):35-47.

Niinemets Ü, Keenan TF, Hallik L. A worldwide analysis of within-canopy variations in leaf structural, chemical and physiological traits across plant functional types. New Phytologist. 2015;205(3):973-993.

Oliveira AN, Amaral IL, Ramos MBP, Nobre AD, Couto LB, Sahdo RM . Composição e diversidade florístico-estrutural de um hectare de floresta densa de terra firme na Amazônia Central, Amazonas, Brasil. Acta Amazonica. 2008;38(4):627-641.

Ouyang W, Struik PC, Yin X, Yang J. Stomatal conductance, mesophyll conductance, and transpiration efficiency in relation to leaf anatomy in rice and wheat genotypes under drought. Journal of Experimental Botany. 2017;68(18):5191-5205.

Park SY, Furukawa A. Photosynthetic and stomatal responses of two tropical and two temperate trees to atmospheric humidity. Photosynthetica. 1999;36:181-186.

Peguero-Pina JJ, Sancho-Knapik D, Gil-Pelegrín E. Ancient cell structural traits and photosynthesis in today's environment. Journal of Experimental Botany. 2017;68(7):1389-1392.
Sage RF, Kubien DS. The temperature response of C3 and C4 photosynthesis. Plant, Cell \&; Environment. 2007;30(9):1086-1106.

Schwartz G, Bais ALS, Peña-Claros M, HoogstraKlein M, Mohren GMJ, Arts BJM. Profitability of silvicultural treatments in logging gaps in the Brazilian Amazon. Journal of Tropical Forest Science. 2016;28(1):68-78

Shao HB, Chu LY, Jaleel CA, Zhao CX. Water-deficit stress-induced anatomical changes in higher plants. Comptes Rendus Biologies. 2008;331(3):215-225.

Stinziano JR, Adamson RK, Hanson DT. Using multirate rapid $\mathrm{A} / \mathrm{Ci}$ curves as a tool to explore new questions in the photosynthetic physiology of plants. New Phytologist. 2019;222(2):785-792.

Terashima I, Hanba YT, Tholen D, Niinemets Ü. Leaf functional anatomy in relation to photosynthesis. Plant Physiology. 2011;155(1):108-116.

Tosens T, Laanisto L. Mesophyll conductance and accurate photosynthetic carbon gain calculations. Journal of Experimental Botany. 2018;69(22):5315-5318

Tosens T, Nishida K, Gago J, Coopman RE, Cabrera HM, Carriquí M, et al. The photosynthetic capacity in 35 ferns and fern allies: mesophyll $\mathrm{CO} 2$ diffusion as a key trait. New Phytologist. 2016;209(4):15761590.

Warren CR. Soil water deficits decrease the internal conductance to $\mathrm{CO} 2$ transfer but atmospheric water deficits do not. J Exp Bot. 2009;59(2):327-334.

Xiong D, Douthe C, Flexas J. Differential coordination of stomatal conductance, mesophyll conductance, and leaf hydraulic conductance in response to changing light across species. Plant, cell \& environment. 2018;41(2):436-450.

Yamori W, Noguchi K, Hanba YT, Terashima I. Effects of internal conductance on the temperature dependence of the photosynthetic rate in spinach leaves from contrasting growth temperatures. Plant and Cell Physiology. 2006;47:1069-1080. 